\title{
EMPIRICAL RESEARCH INTO THE COPING OF MARRIAGE PARTNERS WITH DIFFERENT LEVELS OF SUBJECTIVE WELL-BEING
}

\author{
ЕМПІРИЧНЕ ДОСЛІДЖЕННЯ ОСОБЛИВОСТЕЙ КОПІНГУ ШЛЮБНИХ \\ ПАРТНЕРІВ ІЗ РІЗНИМ РІВНЕМ ЇХ СУБ'ЄКТИВНОГО БЛАГОПОЛУЧЧЯ
}

УДК 159.9.07

DOI https://doi.org/10.32843/2663-

5208.2020.14.14

Abramiuk 0.0.

Postgraduate Student

at the Department of Psychology

Ivan Franko National University of Lviv
The article synthesizes the theoretical concepts of foreign and domestic psychologists and presents a model of coping of marriage partners, as well as summarizes and outlines the structure of the subjective well-being of marriage partners. It presents the analysis of the results of our own experimental study of the coping style of marriage partners with different levels of subjective well-being, which revealed qualitative differences in coping of marriage partners in different groups of people with high and low levels of subjective well-being. It has been established that marriage partners with a high level of subjective well-being have a wide range of individual coping tools, as well as make full and balanced use of the possibilities of dyadic coping of spouses. Dominant strategies of individual coping: "problem-solving planning", "positive reappraisal", "social support seeking", as well as anticipatory-preventive and proactive individual coping. Positive effect of proactive coping of marriage partners has been confirmed to be achieved if it is supported by high-quality dyad interaction and lack of competition between partners. In the context of marital interaction with stress, the effectiveness of the choice of emotionally-focused coping strategies, as well as the use of dyadic coping when a person faces stressors is noted. Dyadic coping in the face of stress has a synergistic effect and has a positive effect on the functioning of the family system and the subjective well-being of marriage partners. At the same time, the constructive activity of each of the marriage partners in the form of individual coping promotes personal growth, strengthens self-confidence and allows avoiding overloading the partner, thereby preventing their emotional burnout. It is summarized that coping of marriage partners, realized through conscious and active actions to mitigate or overcome their own stress and balanced use of resources and opportunities of each other to cope with stressful situations together, has a direct positive impact on the quality of marriage, enhances the importance of partners for each other, it enhances their quality of life and the personal subjective well-being in marriage.

Key words: person's subjective well-being in marriage, coping of marriage partners, individual coping in marriage, proactive coping within marriage, dyad coping of spouses.

У статті синтезовано теоретичні концепції зарубіжних та вітчизняних психологів та представлено модель копінгу шлюбних партнерів, а також підсумовано та окрес- лено структуру суб'єктивного благополуччя шлюбних партнерів. Представлено аналіз результатів власного експериментального дослідження особливостей копінгу шлюбних партнерів із різним рівним їх суб'єктивного благополуччя, де виявлено якісні відмінності копінгу шлюбних партнерів у різних групах осіб із високим та низьким рівнем суб'єктивного благополуччя. Установлено, що шлюбні партнери з високим рівнем суб'єктивного благополуччя володіють широким арсеналом індивідуального копінгу, а також повною мірою та збалансовано використовують можливості діадного копінгу подружжя. Домінуючі стратегії індивідуального копінгу: планування вирішення проблем, позитивна переоцінка, пошук соціальної підтримки, а також антиципаторно-превентивний та проактивний індивідуальні копінги. Підтверджено, що позитивний ефект проактивного копінгу шлюбних партнерів досягатиметься у разі підкріплення його якісною діадною взаємодією та відсутністю конкуренції в парі. у контексті подружньої взаємодії зі стресом відзначено ефрективність вибору емоційно-орієнтованих копінг-стратегій, а також застосування діадного копінгу у разі зіткнення особи зі стресочинниками. Діадний копінг у разі зіткнення зі стресом дає синергічний ефект та позитивно впливає на ффункціонування сімейної системи та суб'єктивне благополуччя шлюбних партнерів. При цьому конструктивна активність кожного зі шлюбних партнерів у вигляді індивідуального копінгу сприяє власному особистісному зростанню, посилює впевненість у власних силах та дає змогу не перенавантажувати партнера, тим самим чинить профрілактику його емоційного вигорання. Резюмовано, що копінг шлюбних партнерів, реалізовуючись через усвідомлені та активні дії щодо пом'якшення чи подолання власних стресових навантажень та збалансоване використання ресурсних станів та можливостей один одного для проходження стресових ситуацій разом чинить безпосередній позитивний вплив на якість подружніх стосунків, посилює значущість партнерів один для одного, підвищує їхню якість життя та суб'єктивне благополуччя особистості в шлюбі.

Ключові слова: суб'єктивне благополуччя особистості в шлюбі, копінг шлюбних партнерів, індивідуальний копінд у шлюбі, проактивний копінг у шлюбі, діадний копінг подружжя. 
Formulation of the problem. The current stage of society development is characterized by rapid political, economic and social transformations, changes in moral ideals, the rapid transformation of social phenomena and human destabilizing processes. Such turbulence is inevitably accompanied by a high level and prolonged nature of stress in modern humans, so today it is extremely important to find and understand possible sources of support in such a rapidly changing world. In this context, the problem of overcoming difficult life situations and the search for resources that reduce or eliminate stress is extremely relevant and is particularly relevant for psychological science. An important role in the prevention or elimination of the effects of stress is assigned to the effective use of coping. Skillful and correct use of coping strategies determines the further harmonious development of a person, promotes their self-regulation and constructive interpersonal interaction. Coping of marriage partners expands the range of their opportunities when facing stressors and opens the way to find a resource model of the family which creates the necessary conditions for the fulfillment of personal potential of each of its members and human happiness.

Analysis of recent research and publications. The phenomenon of individual well-being in modern psychological science was studied by N. Bradburn, E. Diener, M. Yahoda, C. Riff, M. Seligman, M. Argyle, W. Wilson, A. Waterman, R. Ryan, E. Deci, D. Kahneman, A. Voronina, I. Dzhydarian, R. Shamionov, L. Kulykov, N. Fetiskin, O. Shyriaieva, T. Shevelenkova, P. Fesenko, etc.. The Organization for Economic Co-operation and Development (OECD) has reached a consensus among experts in various fields, including psychology, on the use of the term "subjective well-being", which goes beyond the classical definition given by $\mathrm{E}$. Diener [15]. Based on a thorough analysis of scientific publications and a holistic approach to the study of subjective well-being, as well as the feasibility of using an integrated approach to its operationalization, the conceptual structure of subjective well-being is formed by emotional, cognitive and "eudemonistic" components $[1 ; 7 ; 9 ; 15 ; 16]$. In the light of this study, the work of $\mathrm{V}$. Tkachenko is interesting. He described the factors of marital well-being, which is an integral condition for the formation of a sense of subjective well-being of spouses. The author emphasizes the personal maturity of marriage partners as a determining factor [8], which is consistent with foreign research and describes the "eudemonistic" component of the subjective well-being of the individual.

In foreign psychology, thorough research into coping is described in the works of such researchers as: R. Lazarus, L. Murphy, R. Moos, M. Seligman, S. Volkman, E. Freidenberg, S. Hobfoll, R. Schwarzer, E. Greenglass, L. Aspinwall, Sh. Tay- lor, etc.[3]. A direct scientific appeal to the study of the peculiarities of the formation and maintenance of stable patterns of functioning under the influence of stress was initiated in psychology within the transactional theory of stress presented in the works of R. Lazarus and S. Volkman. Thus, coping can be formed through learning a person is able to learn new ways to overcome, rethink the effects and significance of stress, expand their knowledge and ideas about ways to mitigate, overcome, and form and consolidate sustainable situational actions to eliminate stress and reduce tension. That is why the concept of "coping" has become increasingly developed and popular and sounds today as a powerful resource for individuals in the face of objectively and subjectively significant stressor, and also includes a response not only to excessive demands or those that exceed human resources, but also to daily stressful situations.

Theoretical and empirical developments in family stress and coping are described in the works of G. McCabe and J. Petterson, W. Thompson, S. Carter, R. Kessler, P. Watzlawick, G. Bodenmann, T. Kriukova, O. Kuftiak, N. Bielorukova and other foreign researchers, concerning the manifestation of the most significant stresses for family life, as well as ways to overcome them. A thorough analysis of current research into coping within a family concludes that the first attempts to eliminate a difficult situation, its transformation or adaptation thereto usually use individual coping styles and strategies, and after unsuccessful attempts at individual coping or in situations where stressors affect both partners, group or dyad coping is used [4;6]. However, family and marital coping is seen in foreign studies as a stabilizing factor in the homeostasis of the family system, and the supporting influence of the social environment, especially the family, is seen as a powerful resource for the individual and their well-being [10-12]. While the Western scientific community has been actively working on the problem of family stress management in recent decades, in the Ukrainian scientific environment, the psychology of coping in marriage is in its infancy and is underdeveloped. Today, there is little empirical data describing the constructive conscious activity of marriage partners in stressful situations, so empirical research into the impact of coping of marriage partners on their subjective well-being is relevant and will help advance in finding opportunities for a person to remain optimally functioning under stress.

Formulating the goals of the article. The purpose of the article is to present an empirical research into the coping style of marriage partners with different levels of subjective well-being, to identify factors that allow partners to feel satisfied with life and contribute to the full functioning of the individual in marriage. 
To reach the set objective, we need to perform the following tasks:

1) explore and describe the coping styles of marriage partners with different levels of subjective well-being;

2) identify the specifics of coping of marriage partners and its relationship with marital satisfaction;

3) identify the dominant strategies that allow marriage partners to be satisfied with life, marriage, feel emotionally comfortable, as well as fully realize their personal potential.

The main material. The subjective well-being of marriage partners is considered as an integral dynamic formation that does not provide for the simultaneity of positive vectors in all spheres of activity, is characterized by a diachrony of different components, but is formed by a certain critical accumulation and experience reflection [15]. Cognitive, emotional and eudemonistic components are distinguished in the structure of subjective well-being. The cognitive component of well-being arises in the presence of a holistic, consistent picture of the world, understanding of the life situation, including family situation, the ability to distinguish their own irrational (mythical) judgments about the partner and reconstruct them into adequate realities. The emotional component of well-being reflects an individual's assessment of their own emotional state: if positive affect dominates over negative one, a feeling of security and emotional comfort is formed. The eudemonistic component of well-being reflects the presence of clear life goals, the success of plan implementation, the availability and awareness of resources and conditions to achieve these goals. Diagnostic tools that describe the above components of the subjective well-being of marriage partners include the below techniques:

1. Satisfaction with Life Scale (SWLS), E. Diener;

2. Subjective Well-Being Scale A. Perrudet-Badoux at al. adapted by M. Sokolova;

3. Psychological Well-Being Scale Questionnaire by C. Riff adapted by T. Shevelienkova and P. Fesenko.
In addition, the method of marital satisfaction assessment was used: Marital Satisfaction Test Questionnaire (V. Stolin, T. Romanova, $\mathrm{H}$. Butenko); as well as the Thomas-Kilmann Conflict Mode Instrument (TKI) adapted by N. V. Hrishyna. These techniques will reflect the quality of intra-family interaction between marriage partners and the level of satisfaction with their relationship as a couple.

Based on a thorough analysis of foreign publications and a synthesis of concepts of person's coping, taking into account the peculiarities of the family system functioning, specific forms of coping for marriage partners are singled out (Fig. 1) [2]. They will describe their own cognitive, emotional and behavioral efforts aimed at overcoming or mitigating, adapting to or deviating from the requirements of a situation, which is subjectively assessed by a person as stressful, associated with a system of directed actions, predicting the outcome of the process, creative generation of new ways out and solutions to a difficult or tough situation, as well as overcoming or reducing tension as a result of partner support, active cooperation and coordination of coping strategies by the couple.

Based on the theoretical analysis of research and the above-described structure of coping of marriage partners, the research methods are as follows:

1. Ways of Coping Questionnaire (WCQ) P. Lazarus, S. Volkman, adapted by T. Kriukova, Ye. Kuftiak, M. Zamyshliaieva;

2. Proactive Coping Inventory (PCl), E.R. Greenglas, R. Schwarzer and S. Taubert, adapted by Ye. Starchenkova;

3. Dyadic Coping Inventory (DCl), G. Bodenmann, ad.by Ye. Kuftiak.

Statistical data processing was performed using STATISTICA 10.0 software, cluster analysis, descriptive statistics, Pearson's correlation coefficient, one-way analysis of variance and the method of multiple comparisons, and the Scheffe test.

To achieve these goals, an empirical study was conducted with the participation of 200 people.

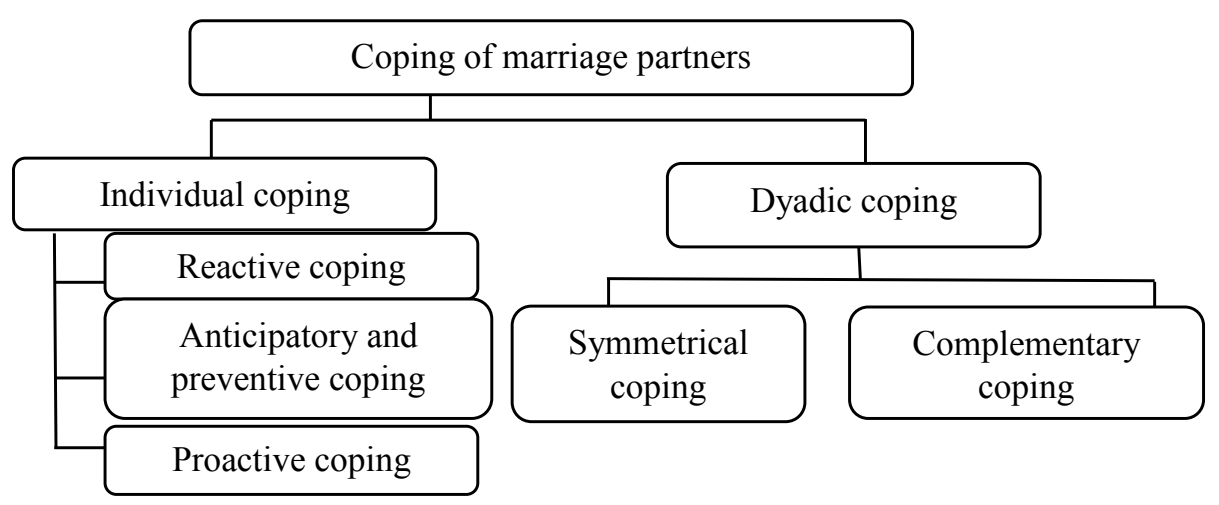

Fig. 1. Structure of marriage partners coping 
The study focuses on 100 couples with different family experience from one to 37 years. The studied couples who voluntarily agreed to participate in the study are in an officially registered marriage, their family is couple family, functioning and is not one of the "at risk" families.

Using cluster analysis, respondents were divided into three groups: the first group included 64 people with a high level of subjective well-being $(32 \%)$, the second group included 45 people with the lowest level of subjective well-being (22.5\%), and the third group included 91 people with an average level of subjective well-being (45.5\%). The average values and standard deviation of the indicators of subjective well-being and marital satisfaction of the respondents are shown in Table 1.

The average value of marital satisfaction is high in the general study group, because the marriage partners of both the first and third groups can be characterized as those who are satisfied with the quality of their family relationships. These indicators for assessing the quality of marital relations by persons of the first and third groups also correlate with the basic indicators of subjective well-being of the individual, reflecting the three-component structure of subjective well-being. Individuals of the first group are most satisfied with life in general; low rate of emotional discomfort indicates that such persons do not have serious emotional problems, they are confident enough, active, successfully interact with others, so, we can note the prevalence of positive emotions over negative ones; the indicator of eudemonistic subjective well-being indicates that the marriage partners of this group are able to establish and maintain close and trusting relationships, care for and demonstrate empathy for others, accept themselves, feel confident and competent in managing daily affairs aimed at personal growth and optimal fulfillment of their potential, are aware of their own life prospects. These data are consistent with the latest research [13; 14], which emphasizes that people who are satisfied with their marriage feel more prosperous.

The indicator of marital satisfaction of persons from the second group indicates a lower quality of marital interaction between partners. Of particular note is the indicator of emotional comfort, which indicates tension and emotional discomfort of the subjects from the second group. In addition, the average value of overall life satisfaction indicates general dissatisfaction with life among the spouses of the described group. The subjects of the second group are characterized primarily by the inability to cope with everyday affairs, feel unable to improve their living conditions and helpless in managing the surrounding world (Menv. manag. $=49.2$ ), they are more dissatisfied with themselves, concerned about some personality traits, do not accept themselves holistically, mostly negatively evaluate their past, which allows us to state a lower level of subjective well-being of marriage partners in this group and the existence of barriers to their full functioning and realization of their personal potential.

To determine differences in the coping of marriage partners in three groups with different levels of subjective well-being, statistically significant differences in the data of the three clusters were analyzed using one-way analysis of variance and the method of multiple comparisons, the Scheffe test. The results of the Scheffe test are given in Table 2.

Thus, the analysis of the data shows a statistically significant difference between the indicators of both individual and dyadic coping of marriage partners in the formed groups. The differences are higher in the two groups - with high and low level of subjective well-being of spouses, which gives grounds to make a preliminary conclusion that a wide range of coping tools used by marriage partners allows them to be satisfied with life and marital relations, feel emotional comfort and live full life. It should be noted that the indicator of the strategy of "problem solving planning" is high in the first and third groups, i.e. problem solving in the studied groups of persons takes place through the purposeful analysis of the situation and possible behaviors, marriage partners plan their actions based on objective conditions, past experience and resources, whether they are own or social. Given that scholars [3; 5] consider this strategy to be one of the most effective in overcoming stress, and the fact that the average marital satisfaction in both groups is high and marriage partners, referring to the scale of the marital satisfaction test-questionnaire, consider themselves to be prosperous on average, we can say that problem-focused coping is a powerful resource that helps to overcome life's difficulties and cope with stress. This strategy contributes to the overall satisfaction with life, provides inner emotional comfort and positive functioning of the individual, as well as maintains a high level of viability of the family system and its well-being.

It is important to note a significant difference between the two groups in terms of individual coping strategy "positive reappraisal", which is to overcome the negative feelings about the problem through positive rethinking, considering it as an incentive for personal growth. The first group is characterized by a rethinking of life's difficulties and stresses in a positive light, they are focused on philosophical understanding of the problem situation and its inclusion in the broader context of work on own development. The strategy of "positive reappraisal" is not pronounced as one of the coping strategy tools used by marriage partners who are in the second group with a lower level of subjective well-being, which suggests that this form of individual coping is an important 
Average results for subjective well-being and marital satisfaction in different groups

\begin{tabular}{|l|c|c|c|c|c|c|c|c|}
\hline \multirow{2}{*}{ Indicator Name } & \multicolumn{2}{|c|}{$\begin{array}{c}\text { Total for } \\
\text { the group }\end{array}$} & \multicolumn{2}{c|}{$\begin{array}{c}\text { Group 1 - } \\
\text { people with } \\
\text { a high level } \\
\text { of SWB }\end{array}$} & \multicolumn{2}{c|}{$\begin{array}{c}\text { Group 2- } \\
\text { people with } \\
\text { a low level } \\
\text { of SWB }\end{array}$} & \multicolumn{2}{c|}{$\begin{array}{c}\text { Group 3 } \\
\text { average level } \\
\text { of SWB }\end{array}$} \\
\cline { 2 - 9 } & M & SD & M & SD & M & SD & M & SD \\
\hline Marital satisfaction & 37.77 & 6.45 & 41.69 & 3.69 & 31.6 & 7.54 & 38.05 & 4.97 \\
\hline $\begin{array}{l}\text { Life satisfaction } \\
\text { (cognitive component) }\end{array}$ & 25.4 & 6.09 & 28.9 & 4.9 & 19 & 5.8 & 26.09 & 4.31 \\
\hline $\begin{array}{l}\text { Emotional discomfort } \\
\text { (emotional component) }\end{array}$ & 52.33 & 14.1 & 38.09 & 7.04 & 70.51 & 9.58 & 53.35 & 7.1 \\
\hline $\begin{array}{l}\text { Psychological well-being } \\
\text { (eudemonistic component) }\end{array}$ & 364.2 & 37.8 & 403.5 & 20.9 & 317.98 & 25.7 & 359.5 & 18.6 \\
\hline
\end{tabular}

Table 2

Differences in marriage partner coping for three groups with different levels of subjective well-being

\begin{tabular}{|c|c|c|c|c|c|c|}
\hline \multirow{2}{*}{ Indicator Name } & \multicolumn{2}{|c|}{ Group 1} & \multicolumn{2}{|c|}{ Group 2} & \multicolumn{2}{|c|}{ Group 3} \\
\hline & $\mathbf{M}$ & SD & $\mathbf{M}$ & SD & $\mathbf{M}$ & SD \\
\hline Competition strategy (by Thomas) & $2.69^{*}$ & 2.22 & 4.44* & 3.05 & 3.38 & 2.6 \\
\hline Distancing (according to Lazarus) & $46.7^{*}$ & 14.5 & $54.32^{*}$ & 14.88 & 48.96 & 16.56 \\
\hline Social support seeking (according to Lazarus) & 70.92* & 15.92 & $62.35^{*}$ & 16.06 & $63.68^{*}$ & 18.24 \\
\hline $\begin{array}{l}\text { Acceptance of responsibility (according to } \\
\text { Lazarus) }\end{array}$ & $58.72^{*}$ & 16.29 & $67.59^{*}$ & 20.89 & 60.53 & 16.98 \\
\hline Escape-avoidance (according to Lazarus) & 43.29* & 15.33 & $57.22^{*}$ & 11.9 & 48.08* & 14.34 \\
\hline Problem solving planning (according to Lazarus) & $80.30^{*}$ & 14.14 & $66.05^{*}$ & 13.62 & 73.99* & 16.75 \\
\hline Positive reappraisal (according to Lazarus) & 72.99* & 14.3 & $57.14^{*}$ & 14.14 & $62.85^{\star}$ & 15.18 \\
\hline $\mathrm{DCl}$ (dyadic coping) & $140.7^{*}$ & 16.14 & $114.3^{*}$ & 14.6 & 128.87 & 15.34 \\
\hline Messages I send about my stress & $15.19^{*}$ & 2.84 & $13.02^{*}$ & 2.45 & 14.01 & 3.25 \\
\hline Own supporting dyadic coping & $20.7^{*}$ & 2.63 & $18.38^{*}$ & 2.55 & $19.24^{*}$ & 2.81 \\
\hline Own emotionally-focused supportive coping & 12.56* & 1.67 & $10.96^{*}$ & 1.77 & $11.68^{*}$ & 1.84 \\
\hline Own problem-focused supportive coping & $8.09^{*}$ & 1.42 & $7.42^{*}$ & 1.12 & $7.55^{*}$ & 1.35 \\
\hline Own delegated dyadic coping & 7.72* & 1.35 & 6.73* & 1.27 & 7.32* & 1.26 \\
\hline Own negative dyadic coping & $17.84^{*}$ & 2.5 & $14.33^{*}$ & 3.16 & $16.63^{*}$ & 2.73 \\
\hline Own dyadic coping & 46.27* & 5.32 & $39.44^{*}$ & 5.56 & 43.19* & 5.29 \\
\hline Partner's message abo & $14.67^{*}$ & 2.81 & $12.31^{*}$ & 2.89 & 13.24* & 2.96 \\
\hline Supportive dyadic & 20.3 & 3.36 & $15.64^{\star}$ & 3.5 & $18.2^{*}$ & 3.38 \\
\hline focused supportive coping & $12.48^{*}$ & 1.96 & $9.4^{\star}$ & 2.26 & $11.24^{*}$ & 2.23 \\
\hline $\begin{array}{l}\text { Problem-focused supportive coping } \\
\text { of the partner }\end{array}$ & $7.86^{*}$ & 1.69 & $6.27^{*}$ & 1.6 & $6.96^{*}$ & 1.62 \\
\hline ted dyadic coping of the partner & $7.53^{\star}$ & 1.78 & $5.89^{*}$ & 1.56 & $6.77^{*}$ & 1.6 \\
\hline Negative dyadic coping of the partner & $17.11^{*}$ & 2.74 & $12.69^{*}$ & 3.01 & $15.85^{*}$ & 2.83 \\
\hline Dyadic coping of the partner & 44.98* & 6.48 & $34.22^{*}$ & 6.65 & 40.81* & 6.45 \\
\hline Joint dyadic coping (JDC) of the couple & $19.61^{*}$ & 3.55 & $15.33^{*}$ & 3.58 & 17.62* & 3.2 \\
\hline Problem-focused JDC & $12.61^{*}$ & 2 & $10.33^{*}$ & 1.98 & $11.69^{*}$ & 1.88 \\
\hline Emotionally focused JDC & $6.89^{*}$ & 1.94 & $5^{*}$ & 2.08 & $5.91^{*}$ & 1.9 \\
\hline Evaluation of dyadic coping of the couple & $8.31^{*}$ & 1.41 & $5.91^{*}$ & 1.82 & $7.57^{*}$ & 1.84 \\
\hline Proactive coping & 45.77* & 4.81 & $36.38^{*}$ & 5.45 & 42.57* & 5.14 \\
\hline Reflexive coping & 34.64* & 5.36 & $30.78^{*}$ & 5.75 & 33.33 & 5.97 \\
\hline Strategic coping & & 2.78 & $9.67^{*}$ & 2.67 & $10.92^{*}$ & 2.64 \\
\hline Preventive coping & $31.72^{*}$ & 5.07 & $26.84^{*}$ & 5.66 & $30.11^{*}$ & 4.54 \\
\hline Search for tool support & $19.64^{*}$ & 4.61 & $17.07^{*}$ & 4.58 & 18.11 & 4.4 \\
\hline Search for emotional support & $14.81^{*}$ & 2.59 & $11.87^{*}$ & 3.4 & 13.2 & 3.13 \\
\hline
\end{tabular}

Note: ${ }^{*}$ - statistically significant differences in the corresponding indicators in groups are noted in bold. 
condition for the subjective well-being. According to Frankl, life has meaning in all its manifestations, so a person can find meaning in times of stress or crisis, and thus is able to change the situation to own advantage. Thus, the development of the ability to analyze and rethink life's difficulties will allow a person not only to cope with stressors, but also to fully realize their personal potential and improve their quality of life.

Statistically significant differences were also identified for such coping strategies as "social support seeking", "acceptance of responsibility", "distancing" and "escaping-avoidance", with the first strategy being pronounced in people with a higher level of subjective well-being in comparison with the other two groups, and the last three strategies being typical of the second group people with the lowest level of subjective well-being. Coping strategy "social support seeking" is one of the most powerful coping resources of the individual. It should be noted that social support serves as a kind of protection against stressful events, which prevents physical and mental illness in crisis and stressful situations, leads the subject to think that he/she is loved, appreciated, cared for, and can directly improve physical and psychological well-being of the individual [10]. The high indicator of the strategy "social support seeking" suggests that the respondents of the first group consider appealing to family, relatives, immediate social environment as an important source of self-support and a means of solving family, domestic, economic and social problems. It should be noted that social support, however, can have a negative effect, which is primarily associated with inappropriate support, which can lead to loss of control and helplessness of the partner receiving support, and emotional exhaustion of the partner providing support. However, with an active and sensible attitude of the individual to their own resources, as well as use of individual coping problem-focused strategies, anticipatory-preventive and proactive copying, such negative consequences can be avoided, while maintaining a balance between self-sufficiency and social support, which is confirmed by the results of this empirical research.

The strategy of "acceptance of responsibility", which in our study was more pronounced in the respondents of the 2 nd group, implies recognition of its role in the problem and is accompanied by efforts to solve it. However, it should be noted that the intensity of this strategy can lead to unjustified self-criticism and self-blame, feelings of guilt and chronic self-dissatisfaction, as stated by the results of the empirical research. Given this, we should state that the moderate level of this coping contributes to the well-being of marriage partners, and it is optimal in the first group. The indicators of the "distancing" strategy of the respondents from the study group are not high, which indicates its infrequent use: people with a high level of subjective well-being use it less than people with a lower level of subjective well-being. It should be added that the moderate level of this coping strategy, which in various stressful situations is aimed at reducing the importance of stress, thus supports mental well-being, "saves" emotional resources. Also of interest is the comparison of the escape-avoidance coping strategy. This strategy is considered by the authors of the method to be generally unconstructive, and the individual overcomes negative feelings caused by difficulties by responding by the type of evasion: denial of the problem, fantasizing, unreasonable expectations, distraction, etc. In the second group of subjects, this figure is higher than in the first group. Thus, given the statistically significant difference in indicators, it is necessary to summarize the confirmation of the conclusions of the methodology authors about the ineffectiveness of such a strategy, in particular both for the subjective well-being of the individual and for the well-being of the family system as a whole.

Statistically significant differences between proactive and anticipatory-preventive (scales of reflexive, strategic and preventive coping) coping in the first and second groups also emphasize the importance of individual coping of marriage partners in the context of the family system. Empirical data confirm the importance of the activity of marriage partners as subjects of influence and the prospect of managing their own and common family goals contrary to traditional risk management in difficult life situations in reactive coping, which promotes personal self-realization of marriage partners and improves their quality of life. It should be noted that empirical data confirm the hypothesis described in previous publications that the positive effect of proactive coping of marriage partners will occur if supported by high-quality dyadic interaction and lack of competition between the partners [2]. Thus, the identified statistically significant differences in the groups in terms of competition strategy suggest the importance of the lack of competitive interaction between the spouses. The peculiarity of the first group is the lowest level of competition in conflict situations, i.e. in the event of a conflict partners take into account not only their own interests, but take care of the interests of the other party, which is extremely important for resolving family conflicts. In the second group, the indicator of the competition strategy is more pronounced, which indicates a decrease in the quality of intra-family interaction due to the competing positions of partners.

The use of individual coping described above allows a person to realize their own life goals and reference points, so difficult situations can be considered as a prerequisite for setting life goals and objectives, through which a person becomes able to cope with stress and life chal- 
lenges the person faces. Successful overcoming of difficult life circumstances is accompanied by personal growth of marriage partners, as well as the development of quality relationships in the marriage dyad.

Statistically significant differences in the formed groups should also be noted on most scales of dyad coping - in the first group of subjects the indicators are significantly higher, which indicates the interaction of dyadic coping and subjective well-being of marriage partners, which will be described in more detail after correlation analysis.

As a result of Pearson's correlation analysis for the studied group (at $p<0.01$ ), the closeness of links between the indicators of subjective well-being of marriage partners and the indicators of their individual (Table 3) and dyadic (Table 4) coping was established.

There are direct correlations between the indicators of individual coping strategies "problem solving planning", "positive reappraisal", proactive coping and indicators of subjective well-being of partners, which confirms the previous conclusions about the effectiveness of coping in overcoming difficulties and reducing stress in the family. The ability to apply them effectively contributes to the overall life satisfaction, improves the quality of life and leads to positive functioning of the individual. Inverse correlations of the strategy "escape-avoidance" with the indicators of subjectivewell-being suggest that the person using this strategy is dissatisfied with himself/herself, is insecure as to own strengths and competencies to influence the outside world, has difficulty establishing and maintaining close relationships, feels emotional discomfort and is dissatisfied with own living conditions. The competitive position of marriage partners in resolving conflicts increases their emotional discomfort, reduces intimacy in relationships, distances partners from each other, however, the inverse correlation with the scale "life goals" $(r=-0.18)$ indicates a tendency to blurring life goals and lack of a holistic life perspective in the subjects, and the inverse correlation with the scale "self-acceptance" $(r=-0.18)$ suggests that those who tend to choose to resolve conflicts in a competitive style do not accept all aspects of their personality and are dissatisfied with themselves.

Correlation analysis shows a close connection between subjective well-being and dyadic

Table 3

\section{Coefficients of correlations between the indicators of subjective well-being and scales of psychodiagnostic methods of response to conflict and individual coping of marriage partners in the study group, $p<0.01$}

\begin{tabular}{|c|c|c|c|c|c|c|c|c|c|}
\hline & \multicolumn{9}{|c|}{ Subjective well-being } \\
\hline & 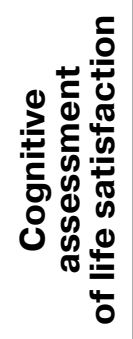 & 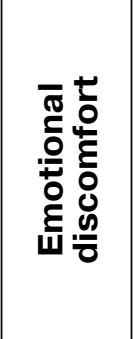 & 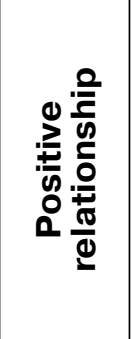 & 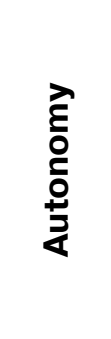 & 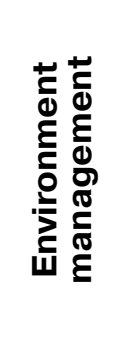 & $\begin{array}{l}\frac{5}{3} \\
\frac{5}{0} \\
\frac{0}{\sigma} \\
\frac{\pi}{0} \\
\frac{9}{0} \\
0\end{array}$ & 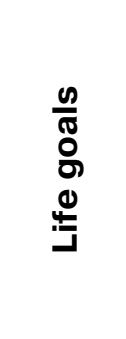 & 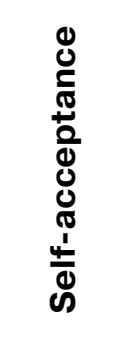 & 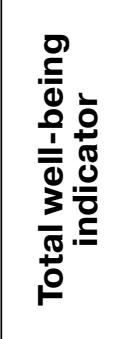 \\
\hline $\begin{array}{l}\text { Competition strategy } \\
\text { (by Thomas) }\end{array}$ & -0.15 & 0.23 & -0.27 & -0.15 & -0.17 & -0.1 & -0.18 & -0.18 & -0.23 \\
\hline $\begin{array}{l}\text { Social support seeking } \\
\text { (according to Lazarus) }\end{array}$ & 0.18 & -0.14 & 0.29 & 0.03 & 0.1 & 0.31 & 0.21 & 0.16 & 0.24 \\
\hline $\begin{array}{l}\text { Escape-avoidance } \\
\text { (according to Lazarus) }\end{array}$ & -0.25 & 0.36 & -0.29 & -0.1 & -0.28 & -0.1 & -0.3 & -0.28 & -0.3 \\
\hline $\begin{array}{l}\text { Problem solving planning } \\
\text { (according to Lazarus) }\end{array}$ & 0.25 & -0.27 & 0.21 & 0.19 & 0.28 & 0.3 & 0.29 & 0.34 & 0.35 \\
\hline $\begin{array}{l}\text { Positive reappraisal } \\
\text { (according to Lazarus) }\end{array}$ & 0.24 & -0.32 & 0.36 & 0.21 & 0.27 & 0.49 & 0.36 & 0.4 & 0.46 \\
\hline Proactive coping & 0.39 & -0.5 & 0.39 & 0.28 & 0.56 & 0.44 & 0.58 & 0.61 & 0.62 \\
\hline Reflexive coping & 0.27 & -0.23 & 0.19 & -0.02 & 0.3 & 0.15 & 0.26 & 0.27 & 0.25 \\
\hline Strategic coping & 0.27 & -0.22 & 0.2 & 0.05 & 0.29 & 0.14 & 0.29 & 0.3 & 0.28 \\
\hline Preventive coping & 0.3 & -0.31 & 0.2 & 0.08 & 0.35 & 0.19 & 0.31 & 0.32 & 0.32 \\
\hline Search for tool support & 0.23 & -0.19 & 0.3 & -0.08 & 0.13 & 0.11 & 0.11 & 0.13 & 0.15 \\
\hline Search for emotional support & 0.4 & -0.35 & 0.44 & 0.05 & 0.34 & 0.16 & 0.26 & 0.33 & 0.35 \\
\hline
\end{tabular}

Note: ${ }^{*}$ - statistically significant correlations at $\mathrm{p}<0.01$ are highlighted in bold. 
Coefficients of correlations between indicators of subjective well-being and scales of psychodiagnostic methods of dyadic coping of marriage partners at $p<0.01$

\begin{tabular}{|c|c|c|c|c|c|c|c|c|c|}
\hline & \multicolumn{9}{|c|}{ Subjective well-being } \\
\hline & 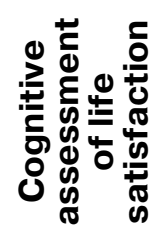 & 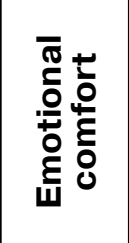 & 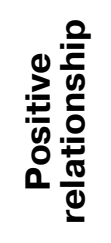 & 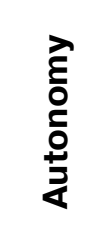 & 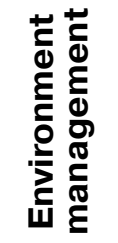 & 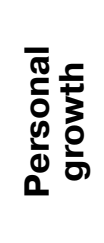 & 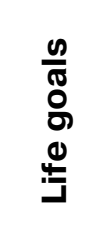 & $\frac{\circlearrowright}{\stackrel{0}{\pi}}$ & 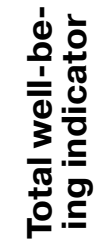 \\
\hline DCl (dyadic coping) & 0.47 & -0.47 & 0.54 & 0.22 & 0.45 & 0.35 & 0.48 & 0.55 & 0.57 \\
\hline $\begin{array}{l}\text { Messages I send about my } \\
\text { stress }\end{array}$ & 0.22 & -0.27 & 0.38 & 0.06 & 0.13 & 0.18 & 0.24 & 0.32 & 0.29 \\
\hline $\begin{array}{l}\text { Own supporting dyadic } \\
\text { coping }\end{array}$ & 0.24 & -0.25 & 0.38 & 0.19 & 0.29 & 0.35 & 0.38 & 0.36 & 0.42 \\
\hline $\begin{array}{l}\text { Own emotionally-focused } \\
\text { supportive coping }\end{array}$ & 0.25 & -0.26 & 0.41 & 0.17 & 0.34 & 0.34 & 0.39 & 0.38 & 0.27 \\
\hline & 0.17 & -0.14 & 0.22 & 0.16 & 0.12 & 0.26 & 0.25 & 0.22 & 0.27 \\
\hline $\begin{array}{l}\text { Own delegated dyadic } \\
\text { coping }\end{array}$ & 0.15 & -0.2 & 0.39 & 0.16 & 0.27 & 0.23 & 0.29 & 0.33 & 0.37 \\
\hline Own negative dyadic coping & 0.3 & -0.32 & 0.37 & 0.21 & 0.36 & 0.34 & 0.37 & 0.42 & 0.45 \\
\hline Own dyadic coping & & -0.33 & 0.46 & 0.24 & 0.38 & 0.39 & 0.44 & 0.46 & 0.52 \\
\hline $\begin{array}{l}\text { Partner's message about } \\
\text { stress }\end{array}$ & 0.29 & -0.28 & 0.22 & 0.18 & 0.26 & 0.03 & 0.21 & 0.28 & 0.27 \\
\hline $\begin{array}{l}\text { Supportive dyadic coping } \\
\text { of the partner }\end{array}$ & 0.42 & -0.42 & 0.46 & 0.14 & 0.44 & 0.31 & 0.43 & 0.48 & 0.49 \\
\hline $\begin{array}{l}\text { Emotionally focused sup- } \\
\text { portive coping of the partner }\end{array}$ & 0.4 & -0.39 & 0.5 & 0.15 & 0.43 & 0.31 & 0.43 & 0.49 & 0.51 \\
\hline $\begin{array}{l}\text { Problem-focused supportive } \\
\text { coping of the partner }\end{array}$ & 0.37 & -0.37 & 0.31 & 0.09 & 0.34 & 0.24 & 0.33 & 0.37 & 0.37 \\
\hline $\begin{array}{l}\text { Delegated dyadic coping } \\
\text { of the partner }\end{array}$ & 0.46 & -0.31 & 0.33 & 0.06 & 0.24 & 0.14 & 0.23 & 0.38 & 0.3 \\
\hline $\begin{array}{l}\text { Negative dyadic coping } \\
\text { of the partner }\end{array}$ & 0.4 & -0.39 & 0.43 & 0.14 & 0.41 & 0.31 & 0.41 & 0.42 & 0.46 \\
\hline Dyadic coping of the partner & 0.49 & -0.45 & 0.49 & 0.14 & 0.45 & 0.32 & 0.44 & 0.51 & 0.52 \\
\hline $\begin{array}{l}\text { Joint dyadic coping (JDC) } \\
\text { of the couple }\end{array}$ & 0.39 & -0.4 & 0.4 & 0.19 & 0.37 & 0.24 & 0.4 & 0.43 & 0.45 \\
\hline Problem-focused JDC & 0.4 & -0.36 & 0.35 & 0.17 & 0.36 & 0.23 & 0.37 & 0.4 & 0.41 \\
\hline Emotionally focused JDC & 0.28 & -0.33 & 0.35 & 0.19 & 0.29 & 0.21 & 0.33 & 0.36 & 0.38 \\
\hline $\begin{array}{l}\text { Evaluation of dyadic coping } \\
\text { of the couple }\end{array}$ & 0.49 & -0.42 & 0.42 & 0.16 & 0.41 & 0.23 & 0.39 & 0.48 & 0.46 \\
\hline
\end{tabular}

Note: ${ }^{*}$ - statistically significant correlations at $\mathrm{p}<0.01$ are highlighted in bold.

coping of marriage partners. Empirical research shows that partners who value their ability to read the partner's stress signals, be aware of them, support the partner and take some of the burden in difficult situations, mobilize interpersonal resources that can prevent stress and/or crisis in a close relationship, and also subjectively highest regard for the ability of their partner to support them under the influence of stressors, are more satisfied with life, feel emotionally comfortable, are focused on personal growth and optimal realization of their potential, are aware of their own life prospects. These marriage partners are able to realize the resources of marriage: the efforts of both partners, love and feelings, the need and desire to be together, support, children, sex, etc. This contributes to the preservation and development of marital relations, as well as increase in the value of both the partner and marital relations. Dyadic coping of partners, as a result of which they are able to clearly understand the problem situation, analyze it, choose the most appropriate solution and implement it, has a synergistic effect and helps to cope more effectively with life challenges of marriage partners, increasing their subjective mental well-being, social 
adaptation, quality of marital relations and life in general. Analysis of empirical results of the study confirms the conclusions about the importance and value of dyadic coping in the coping structure of marriage partners and is evaluated by scholars as a resourceful, most productive way to overcome difficulties in the family, increases the value of close relationships and helps bring marital relations to a qualitatively new level $[2 ; 6 ; 11]$.

Conclusions. Empirical research has revealed qualitative differences in the coping of marriage partners with different levels of subjective well-being. It has been established that marriage partners with a high level of subjective well-being have a wider range of individual coping tools, as well as make full and balanced use of the possibilities of dyadic coping of spouses. Dominant strategies of individual coping used by people with a high level of subjective well-being: "problem-solving planning", "positive reappraisal", "social support seeking", as well as anticipatory-preventive and proactive individual coping. Thus, coping of marriage partners, realized through conscious and active actions to mitigate or overcome their own stress and balanced use of resources and opportunities of each other to cope with stressful situations together, has a direct impact on the quality of marriage, and the personal subjective well-being in marriage. Coping allows marriage partners to take responsibility for creating a comfortable environment in the family, rather than passively adapting to existing discomfort, which is a prerequisite for cognitive and emotional components of subjective well-being, and to cope more effectively with life challenges, which contributes to personal growth of each of the marriage partners (eudemonistic component of subjective well-being). The prospect for further research is to verify the findings of an empirical research into coping of marriage partners in a large sample, to identify the impact of all the coping tools used by the marriage partners on the subjective well-being of each of them and the functioning of the family system as a whole.

\section{REFERENCES:}

1. Абрамюк О., Липецька А. Концептуальна структура френомену «суб'єктивне благополуччя» та особливості його вимірювання. Психологія: реальність $i$ перспективи. 2018. Вип. 11. С. 10-17.

2. Абрамюк О.О. Роль проактивного копінгу шлюбних партнерів у структурі копінгу подружжя. Теорія $i$ практика сучасної психології. 2019. Вип. 3. С. 5-11.
3. Абрамюк О.О. Сучасний стан досліджень проблематики копінгу шлюбних партнерів. Науковий вісник Львівського державного університету внутрішніх справ. Серія психологічна. 2018. Вип. 2. С. 3-11.

4. Крюкова Т.Л. Сапоровская М.В., Куфтяк Е.В. Психология семьи: жизненные трудности и совладание с ними. Санкт-Петербург : Речь, 2005. $240 \mathrm{c}$.

5. Крюкова Т.Л. Человек как субъект совладания. Психология совладающего поведения : материалы Междунар. науч.-практ. конср. Кострома : КГУ им. Н.А. Некрасова, 2007. С. 41-44.

6. Куфтяк Е.В. Концепция семейного совладания: основные положения. Медицинская психология в России. 2012. № 5(16).

7. Созонтов А.Е. Гедонистический и эвдемонистический подходы к проблеме психологического благополучия. Вопросы психологии. 07/2006. № 4. C. 105-114.

8. Ткаченко В.Е. Благополучие супружеских отношений и его психологические детерминанты: теоретический анализ. Вісник Чернігівського державного університету ім. Т.Г. Шевченка. Серія «Психологічні науки». 2009. Вип. 74. Т. 2. С. 156-159.

9. Biswas-Diener R., Kashdan T.B., King L.A. Two traditions of happiness research, not two distinct types of happiness. The Journal of Positive Psychology. 2009. Vol. 4. №. 3. P. 208-211.

10. Bodenmann G. Dyadic coping and its significance for marital functioning. Couples coping with stress: Emerging perspectives on dyadic coping. Washington : DC: American Psychological Association, 2005. P. 33-49.

11. Bodenmann G. Dyadic coping and the significance of this concept for prevention and therapy. Zeitschrift fur Gesundheitspsycologie. 2008. № 16(3). S. 108-111.

12. Bodenmann G., Randall A.K. Common Factors in the Enhancement of Dyadic Coping. Behavior Therapy. 2012. Vol. 43. P. 88-98.

13. Mikucka M. The life satisfaction advantage of being married and gender specialization. Journal of Marriage and Family. 2016. № 78. P. 759-779.

14. Nelson-Coffey S.K. Married... with children: The science of well-being in marriage and family life. In E. Diener, S. Oishi, L. Tay (Eds.). Handbook of wellbeing. Salt Lake City. UT: DEF Publishers, 2018. DOI : nobascholar.com.

15. OECD Guidelines on Measuring Subjective Wellbeing. Organization for Economic Co-operation and Development (OECD). Paris: OECD Publishing, 2013. $265 \mathrm{p}$.

16. Ryan R.M., Deci E.L. On happiness and human potentials: A Review of Research on Hedonic and Eudaimonic Well-Being. Annual Reviews Psychol. 2001. № 52. P. 141-166. 